\title{
IAMJ
}

INTERNATIONAL

AYURVEDIC

MEDICAL JOURNAL

\section{CLINICAL ANALYSIS OF SUTIKA PARICHARYA W.S.R TO KASHYAPA SAMHITHA}

\author{
R. Jayalekshmi ${ }^{1}$, R. Magesh $^{2}$
}

${ }^{1}$ Professor \& HOD, Department of Prasuti Tantra and Stri Roga, Ahalia Ayurveda Medical College Hospital, Kerala University of Health Science, Palakkad, Kerala, India, 678557

${ }^{2}$ Professor \& HOD, Department of Rasashastra and Bhaishajya Kalpana, Ahalia Ayurveda Medical College and Hospital, Kerala University of Health Science, Palakkad, Kerala, India, 678557

Corresponding Author: dr.lekshmy83@gmail.com

\section{https://doi.org/10.46607/iamj1809072021}

(Published Online: July 2021)

Open Access

(C) International Ayurvedic Medical Journal, India 2021

Article Received: 15/06//2021 - Peer Reviewed: 24/06/2021 - Accepted for Publication: 25/06/2021

\section{Check for updates}

\section{ABSTRACT}

Pregnancy and childbirth remain one of the leading causes of mortality worldwide for women of reproductive age. Frequent post-partum morbidity \& its association with adverse perinatal outcomes suggest the need for postpartum care for both mother and baby. The number of maternal deaths related to childbirth, in India while considering a civilization can do wonders in concern with Ayurveda. Puerperium is the period following childbirth during which the body tissues, especially the pelvic organ reverts approximately to the prepregnant state both anatomically and physiologically ${ }^{[1]}$. During this period women require more immense care for physical, emotional, and physiological aspects. The management of puerperium is necessary to avoid infection, bleeding, severe anaemia, backache, postpartum psychosis etc. It also promotes the production of milk in sufficient quantity for the nourishment of new-borns and also helps in rapid recovery of the maternal health, so that the mother may be able to resume her normal activities as early as possible. Kashyapa Samhita, also known as Vriddhi jivakiya tantra is one of the earliest treatises on Ayurveda which is consulted especially in the field of Ayurveda Paediatrics, Gynaecology and Obstetrics. A woman who has just given birth to a child followed by the expulsion of placenta is called Sutika. Kashyapa Samhitha mentioned Sutika kala to be six months as all the Dhatus like raktha will resume to their original state by this time and the treatment pattern should be considered only after analysing the status of 
doshas and dhatus. Sutika not managed properly may suffer from $64^{[2]}$ types of puerperal diseases. In Kashyapa samhitha, Ahara (Diet), Vihara (Lifestyle), Aushadi (Medicines) and Ashwasana (Psychological Reassurance), is explained in a detailed manner. Hence, the classical description of Sutika Paricharya along with its scientific interpretation with special reference to Kashyapa samhitha is elaborated here.

Keywords: Sutika Paricharya, Kashyapa samhitha, Ayurveda, Postnatal.

\section{INTRODUCTION}

A woman who has just given birth to a child followed by the expulsion of the placenta is called Sutika ${ }^{[3]}$. The word Sutika refers to the delivered women and paricharya denotes care; so, treatment or care given to the women after delivery is called Sutika paricharya. The specific period for Sutika paricharya is called Sutika kala. Acharya Kashyapa described only one month for the specific dietetics and six month period for a line of treatment for this period ${ }^{[4]}$. Proper treatment of Sutika is as difficult as cleaning unclean, tattered and old cloth ${ }^{[5]}$. The Vathadosha accelerated after childbirth should be pacified first with the action of Snehana and Swedana. A nutritious diet, oral administration of medicated ghee, medicated rice gruel, medicated soup, massage, wrapping of the abdomen with cloth, fomentation of genital organs by making her sit over leather-covered small stool filled with hot bala thaila, fumigation of the body with drugs like guggulu, aguru are detailed in Kashyapa Samhitha. Management of puerperal women according to the place and sex of the child is another highlight of Kashyapa Samhitha.In the list of causes of puerperal fever, the appearance of milk in the breast and grahas are also included. Several puerperal disorders numbering thirty-five in Dusprajata Chikitsaadhyaya of Chikitsa Stana and sixty-four in Sutikopakramaniya Adhyaya of Khila Stana are described. Among these, twenty-five diseases are common at both places thus a total of seventy-four conditions are mentioned in these chapters by Acharya Kashyapa.

\section{SUTIKA PARICHARYA}

1) Manidharana ${ }^{[6]}$ (Use of amulet)

Amulet of trivrut is tied over her head. It is a sort of psychological support to her that may protect her from harmful things.

2) Samanya Paricharya ${ }^{[7]}$ (General care )

Table 1: Samanya Paricharya according to Ahara and Vihara

\begin{tabular}{|l|l|l|}
\hline Days & Ahara & Vihara \\
\hline 3-5 days & 1) Manda & 1) Rakshoghnani dravya \\
& 2) Hitabhojana & 2) Ashwasana \\
& 3) Snehapana & 3)Kukshi, Pristha, Parshwaabhyangasamva- \\
& 4)Snehayuktayavagu with pippali, nagara devoid of la- & hana \\
& vana & in nyubjashayana \\
\hline 7-12 days & Snehayuktayavagu with lavana & 4) Udarapidana \\
\hline 12 days & 1) Kulathayusha & 5) Udaravesthana \\
& 2) Jangalamamsa rasa & 6)Ushnabalatailapuritacarmasana \\
& 3) Grithabharjitashaka & 7)Yoniswedana- priyangvadi drugs \\
\hline 1 Month & Snehana, Swedana, Ushnajalasevana & 8) Ushnodakasnana \\
& & 9) Vishranti \\
& & 10)Yoni Dhupana with kustha, guggulu, aguru \\
& & with ghrita \\
\hline
\end{tabular}

4) Vishista Paricharya ${ }^{[8]}$ (Specific measures) 
Table 2: Specific management according To Desha ${ }^{[9]}$ (living environment)

\begin{tabular}{|l|l|l|}
\hline \multirow{2}{*}{ AnupaDesha } & Ahara & Vihara \\
\cline { 2 - 3 } & $\begin{array}{l}\text { 1) Manda prayoga with agni-balavardhakadravya } \\
\text { 2) Ushnadravyasevana }\end{array}$ & $\begin{array}{l}\text { Swedana } \\
\text { NivataShayana }\end{array}$ \\
\hline JangalaDesha & Snehopachara & Snehopachara \\
\hline SadharanaDesha & Neither too sneha nor rukshadravyas & \\
\hline VideshaJati & Rakta, Mamsaniryuha, Kandamoola, Phala & \\
\hline
\end{tabular}

Table 3: Specific management according to Sex of the Child ${ }^{[10]}$

\begin{tabular}{|l|l|l|}
\hline Days & Sex of child & Aushada pana \\
\hline $5-7$ days & Male & $\begin{array}{l}\text { Tailapana } \\
\text { Deepaniyaaushadhisamsakritayavagupana }\end{array}$ \\
\hline 5-7 days & Female & $\begin{array}{l}\text { Gruthapana } \\
\text { Deepaniyaaushadhisamsakritayavagupana }\end{array}$ \\
\hline After 7 days & Male and female & Manda \\
\hline
\end{tabular}

\section{DISCUSSION}

Mode of action of drugs and procedures in Sutika paricharya

1. Manda (the clear supernatant water in which rice is boiled) is an easily digestible food which is cold impotency is Deepana (Appetizer), Pachana (digestant), Vatanulomaka (pacifies vatadosha).

2. Sneha mixed with Agni balavardhaka dravyas like Pippali and Nagara act as Hridhya (wholesome), Agnideepana (digestive), Amapachana (carminative) and Vatanulomana (pacifies Vatadosha).

3. Snehayavagu (medicated gruel) stimulate the Agni (digestive fire) Laghu (light), Dhatuposhana (nourishment to dhatus), Tarpana (nutritive). It is easily digestible, reduces thirst thus does the maintenance of water in the body.

4. Yusha (medicated soup) prepared of Kulatha is semisolid, rich in protein. It acts as Agnideepaka (kindles digestion), Hitha (wholesome), Anilahara (pacifies vatadosha), Pushti prasadana(nourishing).

5. Mamsa rasa (meat soup) is Preenana (nourishing), Balya (strengthening) and Pranajanana (life-supporting). It alleviates fatigue and is wholesome for the heart. It is a rich source of protein of a high biological value and also has Aminoacid, Vitamin B complex, Iron and Phosphorus.
6. Saka varga (Vegetables) are Madura rasa (Sweet in taste), Sheeta virya (cold in potency) and act as Pachana (digestive). It rich in Cellulose, Protein, Salts, vitamins and has plenty of water content.

7. Ashwasana is the psychological reassurance. The women after delivery should be encouraged by sweetly spoken words and should be encouraged to talk about their feelings and fears with others. It is a process of mental boosting to let her prepare to take care of herself and also her baby due to physical and emotional exhaustion following delivery, due to rigours of labour and inadequate sleep.

8. Snehana (oleation) treatments like Abhyanga (massage) make the body soft, controls Kapha and Vata aggravation, and bestows nourishment to the tissues, good complexion, and colour, gives strength to the body. It acts as rejuvenation, prevents skin from getting excessively dry and thus prevents further dehydration during the postnatal period. Massage tones up muscles of pelvic floor, abdominal and back tissues and relieves muscle spasms. It improves digestion and is also responsible for improved venous blood flow by dilating superficial blood vessels which in turn prevents thrombosis. Abhyanga at lower back, abdomen, flanks in nyubjashayana (hunch back position) helps for proper drainage of lochia and retune the abdominal muscles. 
9. Udarapeedana (abdominal compression) may facilitate uterine stimulation inducing contraction which may result in the expulsion of residual blood clots.

10. Udaraveshtana (Wrapping of Abdomen with a cotton cloth) can be helpful to support the pelvic girdle, strengthen the abdominal muscles, relocate disfigured \& displaced organs during pregnancy to their normal anatomical structure and position, to regain the elasticity of the skin.

11. Yoni swedana(sudation) with drugs are absorbed through transdermal route improves circulation by vasodilatation, alleviates pain, stiffness and spasm. Yoni swedana helps in minimizing the pain and helps in the healing process. Due to fomentation, the blood flow of the local area is increased through vasodilatation. Drugs like priyangu have strong antiseptic and disinfectant properties which help in preventing infection.

12. Yoni Dhupana(fumigation) drugs like Kusta, Agaru, Guggulu may have properties like antimicrobial, anti-inflammatory, and analgesic. Thus, it is an important local treatment to prevent complications like genital infection or puerperal sepsis. It will maintain the hygiene of the perineum. It keeps episiotomy wounds healthy and facilitates a fast-healing process.

\section{CONCLUSION}

It is a well-known fact that certain psycho-somatic changes take place during Sutika-Kala such as loss of weight, backache, loss of body fluid, lacerated genital tract, constipation, mental stress etc which may lead to maternal malnutrition. These risk factors could be partially reduced by facilitating an early recovery process. So, management of Sutika is essential to promote recovery of maternal health so that the mother may become able to resume her normal activities as early as possible. The Sutika paricharya told in Kashyapa samhitha helps in correcting digestive problems, relieves body pains and weakness, provides psychological reassurance, support involution, enhances the production of breast milk, repairs and tone up muscles prevents infection and incidence of excessive bleeding. Acharya Kashyapa has detailed Sutika paricharya to replenish and restore the health of women and can be proved in modern aspect in a more comprehensive and scientific approach.

\section{REFERENCES}

1. DC Dutta edited by Hiralal Konar Textbook of Obstetrics, $7^{\text {th }}$ Edition, Kolkata, New central book agency,2013 Page no-144.

2. P.V. Tewari, Kasyapa samhitha text with English translation, Chaukhamba visvabharati, Varanasi, Reprint edition 2013, khilastana 11/7, page no-577.

3. P.V. Tewari, Kasyapa samhitha text with English translation, Chaukhamba visvabharati,Varanasi, Reprint edition 2013, khilastana 11/ 6,page no- 576.

4. P.V. Tewari, Kasyapa samhitha text with English translation, Chaukhamba visvabharati, Varanasi, Reprint edition 2013, khilastana 10/ 52, page no -582 .

5. P.V. Tewari, Kasyapa samhitha text with English translation, Chaukhamba visvabharati, Varanasi, Reprint edition 2013, khilastana11/46, page no 581.

6. P.V. Tewari, Kasyapa samhitha text with English translation, Chaukhamba visvabharati, Varanasi, Reprint edition 2013, khilastana11/ 181, page no -575.

7. P.V. Tewari, Kasyapa samhitha text with English translation, Chaukhamba visvabharati, Varanasi, Reprint edition 2013, khilastana 11/ 20, page no- 578.

8. P.V. Tewari, Kasyapa samhitha text with English translation, Chaukhamba visvabharati, Varanasi, Reprint edition2013, khilastana11/22, page no- 578 .

9. P.V. Tewari, Kasyapa samhitha text with English translation, Chaukhamba visvabharati, Varanasi, Reprint edition 2013, khilastana 11/28, page no- 579.

10. P.V. Tewari, Kasyapa samhitha text with English translation, Chaukhamba visvabharati, Varanasi, Reprint edition 2013, khilastana 11/32, page no- 579 .

\section{Source of Support: Nil \\ Conflict of Interest: None Declared}

How to cite this URL: R. Jayalekshmi \& R. Magesh: Clinical Analysis Of Sutika Paricharya W.S.R To Kashyapa Samhitha. International Ayurvedic Medical Journal \{online\} 2021 \{cited July 2021\} Available from: http://www.iamj.in/posts/images/upload/1443_1446.pdf 